\title{
János Barcsák
}

\section{The Ending of "Tintern Abbey" and Paul de Man's theory of the performative nature of language}

\author{
The main purpose of this paper is to explain the puzzling changes that occur at the \\ end of Wordsworth's "Tintern Abbey" by the help of a theoretical structure outlined \\ in Paul de Man's essay "Rhetoric of Persuasion (Nietzsche)." Besides, it also argues \\ that the poem can be used to elucidate some theoretical procedures that de Man \\ deploys in another essay of his, "Promises (Social Contract)."
}

The ending of "Tintern Abbey" (ll. 111-159) is certainly a very strange one. It contains several inconsistencies, such as, for example, the unexpected appearance of Dorothy Wordsworth in the poem, or the less conspicuous but perhaps even more surprising fact that the speaker in this last section of the poem appears as a man who knows, possesses and teaches the truth, although the previous parts of the text describe a man tortured by doubts and uncertainty. ${ }^{1}$ These inconsistencies, if we think about them in a purely logical way, make it very difficult for us to interpret this last part of the poem as an organic development from the main body of the text. This, however, is not what we feel when we read "Tintern Abbey." We feel that the speaker's (and Wordsworth's) victory is somehow necessary at the end of this poem of defeat. Even if we cannot immediately explain Dorothy Wordsworth's appearance or the sudden change of tone from the problematic to the assured, we feel that the emergence of the authoritative voice somehow organically follows from the main part of the text. What is more,

1. There is no general critical agreement on this latter point but recent readings tend to lay emphasis on the sceptical and gloomy undertow in the poem. See, for example, Harold Bloom's reading in The Visionary Company: A Reading of English Romantic Poetry (London: Cornell University Press, 1995) or Susan J. Wolfson's in The Questioning Presence: Wordsworth, Keats, and the Interrogative Mode in Romantic Poetry (Ithaca and London: Cornell University Press, 1986).

The AnaChronisT (2003) 85-109 ISSN 1219-2589 
we feel this even in spite of the fact that this main part presents a speaker tortured by doubts, a Wordsworth who desperately and hopelessly struggles against his own irresistible scepticism.

In this paper I will try to show how the concluding part of "Tintern Abbey" can be interpreted as an organic development from the previous parts, and how the unexpected changes that occur at the end of the poem can be accounted for as necessary constituents of the whole. What will help me in accomplishing this task is Paul de Man's theory of the constative and performative functions of language, which he discusses primarily in the essays of his Allegories of Reading. ${ }^{2}$ Having explained how the poem can be interpreted with the help of this theoretical structure, in the last section of this paper I will reverse the original set-up and will try to show how the poem can throw some new light on de Man's theoretical procedures.

\section{I}

The bounds of the present paper will not allow me to give a full account of the whole of the poem. In order to present my reading of the ending of "Tintern Abbey," however, I will still have to give a brief summary of the way I read the main body of the text. To do this, I will start out from the sentence which creates the link between these sections by summing up the result of what is said in the main body of the text and introducing the thoroughly different attitude of the last section.

The first thing that we notice in this sentence is that it opens on a sceptical note. The speaker begins with the clause "Nor perchance, / If I were not thus taught" (1l. 111-2), 3 which expresses his doubt about the theory he presented in lines 88-102. This theory comprises the speaker's central attempt in the poem to handle the problem of the loss that necessarily accompanies the process of growing up: the loss of the direct experience of nature. This loss can be identified as the central theme of the poem, while the main purpose of the speaker throughout is clearly to find compensation for this loss. In this central passage of the poem this compensation is found in a mysterious "presence" which - the speaker

\footnotetext{
2. Paul de Man, Allegories of Reading (New Haven and London: Yale University Press, 1979).

3. When referring to the text of the poem I always use the final version, on which the author made his last emendations in 1845. All parenthesised references are to this edition: William Wordsworth, Lyrical Ballads, and Other Poems, 1797-180o, ed. James Butler and Karen Greed (Ithaca: Cornell University Press, 1993).
} 
would like to believe - is still accessible for him in nature. At the beginning of the closing section of the poem, however, it becomes clear that the compensation the speaker hoped to attain through this presence is not quite satisfactory, or at least he cannot be fully convinced of the validity of his theory of compensation. No matter how much energy he puts into the wording of this theory, no matter how hard he tries to convince his readers and himself that the loss has been compensated for, he cannot really believe in his own idealisations, as is expressed in the lines quoted above ("Nor perchance, / If I were not thus taught").

This doubt, incidentally, is already the second one in the poem. In lines 4950 the speaker expressed similar scepticism in the clause "If this / Be but a vain belief. .." which refers to another attempt at finding compensation, the theory of the compensatory imagination expressed in lines 35-49. In this passage the alienating environment of the city is contrasted with an imaginative recollection of the beauty of nature which is still accessible to an "inward eye" if not to the physical senses. This indirect experience is said to provide compensation for the loss of the direct contact with nature, but then this theory is called into doubt by the lines quoted above.

It seems, therefore, that at the beginning of the closing section of the poem the speaker has reached an impasse. He has made two attempts to prove that he still has some kind of access to nature and, what in this poem is almost identical with this, to the divine, but fails to disperse his lingering doubt about this. He has tried to convince himself that even if the immediate unity with nature that he experienced five years before (in the fictitious chronology of the poem) is a thing of the past, he can still experience this happy union in vicarious ways. However, by the end of the main body of the text he has to realise that he cannot really believe his own theories of compensation.

All this, of course, is not only acknowledged in the lines which openly express doubt but also in the tone of the whole poem, which - in spite of the conscious efforts of the speaker - is full of sadness, and establishes rather than denies the feeling of loss. The "undertow of questions," the doubting voice, that Susan Wolfson talks about, ${ }^{4}$ appears at this point in the poem to be victorious.

This, however, is not the end of the poem. The speaker acknowledges this impasse only in the two lines quoted above and these lines - considered syntactically - are only the subordinate clause of a sentence that asserts exactly the opposite of the desperation that would be the logical consequence

4. Wolfson, p. 61. 
of the impasse, and thus introduces the substantially different attitude of the concluding part of the poem:

Nor perchance,

If I were not thus taught, should I the more

Suffer my genial spirits to decay

(11. 111-113; my italics)

What this sentence suggests is that the normal reaction to the situation described in the previous parts of the poem would be the decay of the "genial spirits" but Wordsworth consciously refuses to allow this to happen. This - as, I think, the text also acknowledges - is an unexpected reaction. What is even stranger, however, is what Wordsworth says in explanation of this reaction:

For thou art with me here upon the banks Of this fair river; thou my dearest Friend, My dear, dear Friend; and in thy voice I catch The language of my former heart, and read My former pleasures in the shooting lights Of thy wild eyes. Oh! yet a little while May I behold in thee what I was once, My dear, dear Sister!

(1l. 114-121)

The appearance of Dorothy Wordsworth at this point in the poem is rather unexpected, to say the least, and it is no less surprising that Wordsworth sees in her a representative of his former self. 5 The real age difference between the two was a mere one and a half years, yet Wordsworth here makes Dorothy represent a stage in his own life which he experienced five years before. These inconsistencies must not, of course, be looked at as inconsistencies but rather as necessary elements in Wordsworth's design. They must be explained; just as the mysterious change in the tone of the poem that goes together with them must be explained. Indeed this latter element is perhaps the most unexpected thing that happens in this closing section of the poem. When he starts talking to Dorothy, the speaker's (Wordsworth's) tone of voice becomes elevated, hymnic and assured, and this is in very sharp contrast to the previous meditative, sometimes enthusiastic but then always

5. Cf. Harold Bloom's reaction in The Visionary Company, p. 137. 
sceptical tone. ${ }^{6}$ The passage following immediately after the one quoted above is a perfect example of this changed tone of voice:

and this prayer I make,

Knowing that Nature never did betray

The heart that loved her; 'tis her privilege, Through all the years of this our life, to lead

From joy to joy...

$$
\text { (ll. 121-125; my italics) }
$$

This "knowing," as has been indicated, has not at all been sure so far, and thus we can say that to Dorothy now the speaker can affirm that which he could not convince himself of: that the access to the divine, to Nature, is and remains always available. An interesting further change here is that the key to this access is now to be found in Nature herself. In the central part of the text the speaker seemed to seek some proof of this access from his own "fallen" position, from within the boundaries of his own self, by giving some rational account of the connection. But what he ended up with this way turned out to be merely hypotheses, which he was unable to confirm. Now that he can affirm the connection to nature by turning to Dorothy, however, it seems that he must see it as something that comes from nature of her own accord. "Only nature," Harold Bloom comments, "has the privilege of leading us from joy to joy." 7 The divine, the text seems to suggest, is inaccessible for us unless it gives itself, and this access - if it occurs - will thus always remain something that is beyond us: it can never be understood or proved, it can only be experienced and affirmed in an act of faith. The rational control must, therefore, be given up completely if one wants to experience this coming of the divine. And this is exactly what happens in this closing section of the poem: the sceptical attitude of the first part is replaced in the last by the mode of faith, which affirms that which cannot be understood or proved.

This change of mode also makes it possible for the speaker to reintroduce and affirm his two earlier theories of compensation (compensatory imagination

6. Thomas McFarland also recognises this movement. He says, "the poem is somewhat restless and uncertain at its beginning, settles down to a broad and deep current of Wordsworthian certainty, and concludes, with the benediction to Dorothy, in some of the most pure and limpid verse Wordsworth ever wrote" (Originality and Imagination [Baltimore and London: The Johns Hopkins University Press, 1985], pp. 69f.).

7. Bloom, p. 138. 
and the "presence"). The two following passages in this section of the poem clearly restate these earlier idealisations but without the element of doubt which accompanied them in the previous part of the poem:

for she [Nature] can so inform

The mind that is within us, so impress

With quietness and beauty, and so feed

With lofty thoughts, that neither evil tongues,

Rash judgments, nor the sneers of selfish men,

Nor greetings where no kindness is, nor all

The dreary intercourse of daily life,

Shall e'er prevail against us, or disturb

Our cheerful faith, that all which we behold

Is full of blessings.

(11. 125-134)

This passage is closely related to the passage about the compensatory imagination (1l. 29-49), as it is based on the contrast between the alienating city life and the memory of nature. ${ }^{8}$ The only difference is that the working of memory is not described here as human action but rather as the gift of Nature herself: she is said to inform our minds actively. Otherwise the ideas are the same: the burden of adult existence and the alienating, impersonal life in the city are about to suffocate us but the memory of nature gives us assurance and a deeper understanding of the truth beyond the appearances. Yet, when comparing these two parts of the poem, we cannot help feeling that something is missing from the second passage which, it appears, is trying to restate in the mode of faith what was impossible to assert in the earlier part of the poem. The whole theory about the "inward eye," about the metaphysical experience - which was in fact the essence of that previous passage - seems to be left out of this restatement. It seems that the assurance and the powerful declaration of a strong faith go together with a certain loss of thoroughness, of epistemological subtlety.

We encounter the same lack of subtlety in the next passage, as well, which seems to restate the second great theoretical and rhetorical attempt at the reestablishment of the connection with the divinity of nature:

8. John A. Hodgson quotes these two passages alternately when talking about the poem's picturing of city life, creating thus a direct connection between the two statements (Wordsworth's Philosophical Poetry, 1797-1814 [Lincoln: University of Nebraska Press, 1980], p. 38). 
Therefore let the moon

Shine on thee in thy solitary walk;

And let the misty mountain-winds be free

To blow against thee: and, in after years,

When these wild ecstasies shall be matured

Into a sober pleasure; when thy mind

Shall be a mansion for all lovely forms,

Thy memory be as a dwelling-place

For all sweet sounds and harmonies; oh! then,

If solitude, or fear, or pain, or grief,

Should be thy portion, with what healing thoughts

Of tender joy wilt thou remember me,

And these my exhortations!

$$
\text { (ll. 134-146) }
$$

We can easily recognise in this passage the theory about growing up, the idea that the wild ecstasies of youth will be compensated for by more mature, more sober adult pleasures. However, the whole theory about that "presence" which seemed to constitute the main part of the argument of the previous passage (1l. 93-102) and which the speaker finally came to doubt is completely missing. It seems that the cost of becoming able to affirm, to believe, is the loss of complexity; it seems that the mode of faith is necessarily accompanied by a loss of control, a loss of conscious mastery. Whereas in the previous part Wordsworth could check himself and could see the weaknesses of his idealisations, now these seem to be let loose and are presented without any epistemological control.

These successful restatements - and this is another, no less significant change in this last section of the poem - also go together with the appearance of futurity. When the speaker in the central part of the text tries to convince the readers and himself of the general validity of his idealisations and is unsuccessful, he talks about his own present state. Now that he manages to affirm these theories, however, he can affirm them only as applying in the future life of Dorothy. It seems that the way in which Wordsworth becomes capable of restating his theories is through presenting them as applying in somebody else's (this time Dorothy's) life and more particularly in the hypothetical future of that person's life. The impossibility in the speaker's present state becomes possible in Dorothy's hypothetical future. The form of the successful affirmation is, therefore, that of the promise made to another.

This is, however, not the only way in which the future appears in this section of the poem. It also appears as the speaker's own future and more particu- 
larly as the dimension of his own possible absence in the future. In other words, the speaker manages to face death at the end of the poem. His personal future has already appeared in the main part of the text in a rather vague, meditative form when looking at the landscape and still having in mind his theory about remembering nature he hopes "That in this moment there is life and food / For future years" (1l. 64-65). Apart from this, however, the central part of the text is characterised by the anxiety about the future. It could even be said that the speaker makes the two attempts at re-establishing the lost unity with nature because he is afraid of the future, because having lost the unity with the divine the only possible futurity for him is his death, his personal finitude. When describing his present situation, the speaker compares himself to "a man / Flying from something that he dreads" (1l. 70-71). Lionel Trilling and Harold Bloom's footnote in The Oxford Anthology of English Literature comments "what he dreads is mortality," ${ }^{9}$ and it is indeed this mortality that the speaker cannot face in the central part of the text. It seems necessary, however, to come to terms with it somehow, for Wordsworth does not finish the poem until the speaker is able to do so. We could even say, therefore, that this is what the changes of the last part of the poem are ultimately needed for. It is only at the cost of making these changes that Wordsworth can face mortality and finish the poem on a reassuring note, very clearly spoken in the mode of faith:

Nor, perchance -
If I should be where I no more can hear
Thy voice, nor catch from thy wild eyes these gleams
Of past existence - wilt thou then forget
That on the banks of this delightful stream
We stood together; and that I, so long
A worshipper of Nature, hither came
Unwearied in that service: rather say
With warmer love - oh! with far deeper zeal
Of holier love. Nor wilt thou then forget,
That after many wanderings, many years
Of absence, these steep woods and lofty cliffs,
And this green pastoral landscape, were to me
More dear, both for themselves and for thy sake!

(ll. 146-159)

9. Harold Bloom and Lionel Trilling, ed., The Oxford Anthology of English Literature (New York, Oxford University Press, 1973), Vol. 4 (Romantic Poetry and Prose), p. 148n. 


\section{II}

The changes that I have described above undoubtedly show some logic. If the hidden theme of the poem is indeed mortality, then it seems necessary that at the close of the poem the speaker should somehow come to terms with the inevitable future of his death. This, however, he can apparently only do through the changes that he effects in the last section of the poem. It is clear then that the said changes are necessary but the questions why they are necessary and why just these ones are necessary have yet remained in the greatest part unanswered. And this is where Paul de Man's essay, "Rhetoric of Persuasion (Nietzsche)" 10 can help us. The part I will select from this essay reflects a typical and central structure in de Man's thought which I will use to explain the logical connections between the different alterations at the end of "Tintern Abbey."

De Man in this part of his essay analyses a Nietzsche text on the identity principle of logic. The identity principle is basically the statement that A, the subject of any logical proposition, must be identical with itself, that is to say, that we cannot ascribe opposite attributes to it. As this statement already shows, the identity principle is in fact based on the principle of non-contradiction, which is essentially the premise that - as Nietzsche himself puts it - "We are unable to affirm and deny one and the same thing." "11 it is this latter principle that Nietzsche analyses to "deconstruct" the former, the identity principle, which, he asserts on the basis of Aristotle's logic, is the ground of all logical truths. He points out thus that the law of non-contradiction either

asserts something about actual entities, as if one already knew this from some other source; namely that opposite attributes cannot be ascribed to them [können]. Or the proposition means: opposite attributes should not be ascribed to it [sollen]. In that case, logic would be an imperative, not to know the true [erkennen] but to posit [setzen] and arrange a world that should be true for us. ${ }^{12}$

Nietzsche here simply asserts that the law of non-contradiction can be understood in two different ways: as a statement about the truth on the basis of a former knowledge of this truth, a statement, that is to say, of our knowing the truth; or, in

10. Paul de Man, "Rhetoric of Persuasion (Nietzsche)," in Allegories of Reading 119-31.

11. Quoted by de Man in "Rhetoric of Persuasion," p. 119.

12. Quoted by de Man in "Rhetoric of Persuasion," p. 120. 
the lack of this previous knowledge, as a logical act that posits what this truth should be. Nietzsche, of course, argues that we can have no access to any prior knowledge and thus the principle of non-contradiction is not necessarily true in itself but is in fact only posited as true. From this it follows that the self-identical A, which depends entirely on this principle, is itself no more than a hypothesis.

This is the argument which de Man analyses in the part of his essay that I would like to discuss at some length. He identifies the two ways of understanding the law of non-contradiction with two different uses of language: when we make statements about the truth on the basis of a former knowledge of this truth we use the constative mode of language, and when we posit what should be true we apply the performative mode. ${ }^{13}$ What is really important for us, however, is that having done this de Man establishes an essential connection between these two modes of language. Thus he goes farther in his argument than the original Nietzsche text did. He does not only say that there are two different ways of interpreting the statement that expresses the law of non-contradiction but that these two interpretations (now reduced to modes of language) are essentially connected to each other: they follow from one another and are the elements of the same structure. He says

the inability to contradict - to state at the same time that $\mathrm{A}$ is and is not $\mathrm{A}$ - is not a necessity but an inadequacy, 'ein Nicht-vermögen.' Something one has failed to do can become feasible again only in the mode of compulsion; the performative correlate of 'I cannot' is 'I [or you] must.' The language of identity and of logic asserts itself in the imperative mode and thus recognises its own activity as the positing of entities. Logic consists of positional speech acts. As such, it acquires a temporal dimension for it posits as future what one is unable to do in the present: all 'setzen' is 'voraussetzen,' positional language is necessarily hypothetical. ${ }^{14}$

It is not quite clear in this passage what de Man means by that "something" we have failed to do. The word seems to refer to the principle of non-contradiction, as if the sentence of which it is the subject asserted that we want to state at the same time that "A is and is not A" and that we fail. This, however, is apparently not what de Man means to say. His meaning is rather that because we know that the only ground for our notion of the identity principle is a human inadequacy (ex-

13. The distinction is originally John Austin's. Cf. John Austin, How to Do Things with Words (Oxford: Oxford University Press, 1962).

14. De Man, "Rhetoric of Persuasion," pp. 123-124. 
pressed in the principle of non-contradiction), we fail to establish the selfidentical A as an unshakeable truth in the constative mode, the mode of "knowing," although this would be absolutely necessary, for the existence of this A is the grounding principle of logic. This interpretation is supported also by the clause "it posits as future what one is unable to do in the present." Now, clearly we do not want to posit in the future our inability to contradict because it is already well-established in the present, but exactly because it is so well established, we cannot in the present unconditionally accept the self-identical A (it being dependent on our incapacity) and thus we must establish it in the future as a hypothesis.

Whatever this passage in fact talks about, however, it is certain that it describes an essential, necessary connection between two modes of speech, whereas Nietzsche only talked about two alternative interpretations not linked in any organic way. For de Man the constative mode, the use of language, which is concerned with simply registering, reflecting the truth as it in itself is, necessarily ends in an "I cannot." But this must not mean the loss of this truth, for this is what all our discourse is built upon. We must, therefore, make this truth feasible again, we must create some possibility of accessing it even if we have failed in our first attempt. We can, however, only do this if we change our mode of language use from the constative to the performative, from the contemplative to the imperative, from the "I cannot" to the "I [or you] must." De Man, of course, qualifies his statement by saying that this structure is only characteristic of "the language of identity and of logic," yet he also makes it clear that all the "metaphysical" texts (like for instance Wordsworth's "Tintern Abbey") were written in this language, and I would even venture to say - still not doing violence to de Man's thought in general - that every text must necessarily be written in "the language of identity and of logic." I think, therefore, that the generalisation of this structure is not at all unjustifiable.

It is not difficult to see that the change of mode de Man discusses here reflects the general structure of the ending of "Tintern Abbey" very well. It describes the organic development from the contemplative "I cannot" to the imperative "I [or you] must" and shows that this is a necessary development. De Man's structure makes it clear that what Wordsworth cannot assert in the constative or knowing mode characterising the main body of his poem, he must posit in the performative mode in the closing section. The doubting, uncertain main body of Wordsworth's poem can thus be identified with the constative mode which always tries to achieve general claims, certain truths, which always 
attempts to master the reality and come to a knowledge of things but must always fail; and the mode of faith at the end of the poem can be identified with the performative mode which posits the inaccessible truth in a hypothetical future. The change of tone in this last section of the poem is, therefore, the result of the inevitable and organic progress from one mode to another, which the structure of Wordsworth's thought makes necessary.

With the help of this structure, however, we can do more than just point out this general development in the text: we can explain some more particular changes at the end of the poem, as well. The unexpected appearance of Dorothy Wordsworth, for example, follows from the necessary presence of the "you" in the second element of de Man's structure. The imperative mode is never simply an "I must," or I would even say that this is never the primary element in it. It is always the "you," the other that makes it possible for us to change the mode and to perform. This performative act can only be done in the form of a promise, and thus we always need another to whom we can make this promise. The appearance of Dorothy at the end of "Tintern Abbey" is, therefore, a structural necessity in the poem even if it appears to be an inconsistency at first sight. Wordsworth can change the mode, can overcome his difficulties only with the help of Dorothy; only through another can he come to terms with his own self.

This overcoming of the difficulties in Wordsworth's poem is done - as I have said - in the form of a promise; and this promise already involves a temporal dimension which is again very similar to the one described by de Man: "it posits as future what one is unable to do in the present." I think that this is indeed exactly what happens at the end of "Tintern Abbey." Wordsworth posits in Dorothy's future what he cannot do in his own present. It is necessary for him, therefore, that Dorothy be in a much earlier stage of development than himself so that he can promise her the future fulfilment of what he cannot in his own present situation see as feasible. Wordsworth, in other words, must become the teacher of Dorothy and, therefore, he must make his sister appear in the poem much younger than she actually was. This inconsistency, therefore, is again revealed by de Man's structure to be a necessary development in the text.

This structure, therefore, - as its use in "Tintern Abbey" shows - is also a description of the general structure of teaching, or rather of "handing down" 15

15. The phrase was used by T. S. Eliot in his "Tradition and the Individual Talent" as a synonym of tradition (in Frank Kermode, ed., Selected Prose of T. S. Eliot [London: Faber and Faber, 1975], p. 38). 
something to the next generation. The poem's structure suggests that this "something" that the teacher or the adult in general must hand down is not primarily the load of information that schools usually burden young people with, but rather an affirmation. An affirmation of that which the adult could never fully convince him/herself of but which he/she has always already needed as the ground of his/her activity and identity. A teacher needs to promise to the students, for instance, that it is worth studying and teaching although we all know even too well that these activities are not always rewarded by the society; he/she needs to affirm to the students that hard work and an honest life will yield success and reward even though he/she cannot really convince even him/herself of the practical validity of these principles; and, ultimately, we must all teach our children that life is worth living even though this is not always easy for us to believe if we think only of our own situation. We need to affirm all this because our children, our students need our authority and our affirmation to be able to face the future, but - as the structure of the poem makes it clear - not primarily for this. We need to promise primarily because of ourselves, because only through this promise made to another can we affirm that which we have always needed as the ground of our own existence and which we have always already believed in. Through this handing down, through assuming the role of the teacher, we just as Wordsworth's speaker - in fact save our own life, we in fact become capable of facing our own future, the inevitable future of death.

This description of the structure of teaching and of the human situation in general might indeed apply in the case of "Tintern Abbey" but is obviously very far from the spirit of Paul de Man's essay. The structure in these two pieces, one might say, is the same, or a very similar one, but the attitude the two authors show towards it is quite different. When, for example, de Man says "it now turns out that the future-projected, prospective assertion was in fact determined by earlier assumptions, that the future truth was in fact past error," ${ }^{16}$ we can argue that he in fact very closely describes the structure of the ending of "Tintern Abbey." It is, however, also clear that de Man does not consider the outcome of this structure - as Wordsworth in my opinion does - to be the final solution to the questions of our life. He just describes this pattern as a particular form of deconstruction which - according to him - Nietzsche happened to use.

This more neutral attitude is, in fact, very useful for us as it draws our attention to a fact which is necessarily present but is just as necessarily suppressed in

16. De Man, "Rhetoric of Persuasion,” p. 124. 
Wordsworth's poem. This fact is that with the emergence of the strong, authoritative voice at the end of the poem, there is a noticeable loss of complexity, a lack of thoroughness. When analysing the changes in the last section of "Tintern Abbey" we could already observe this lack but could not then account for it. Having understood de Man's structure, however, we now can find an explanation for this disturbing and seemingly inconsistent development. We can say, namely, that this lack of complexity is caused by the fact that what we posit in the future - as de Man points out - can only be a hypothesis. The necessary futurity of the statement brings about the change from the actual to the hypothetical, which in turn causes the loss of epistemological subtlety. The performative speech act lacks the thoroughness and profundity of the constative mode even though the latter must necessarily end in an "I cannot" and must, therefore, give way to the mode of compulsion, of the "I [or you] must." The performative use of language is thus always deceptive (from the constative point of view; that is to say, inasmuch as it conveys knowledge of things), even though it is also equally true that the constative use of language is impossible without the performative act. The lack of theoretical subtlety in the statements at the end of "Tintern Abbey" is, therefore, again a necessary development and not a mere inconsistency. It follows from the general structure on which the poem rests.

The paradoxical relationship I have referred to above is, incidentally, fully and masterfully treated in the second half of de Man's essay which we can even read - in the present context - as a kind of critique of Wordsworth's procedures at the end of the poem. In this second half of his essay de Man proves that the performative act is not capable of fully replacing the constative claims of statements. As a result, the constative mode can by no means be fully eliminated, even though its validity is questioned by the performative interpretation. As de Man himself summarises this situation, "the text on the principle of identity established the universality of the linguistic model as speech act, albeit by voiding it of epistemological authority and by demonstrating its inability to perform this very act." 17 This means that with the necessary passage from the constative to the performative we have actually called into doubt the validity of the performative act itself, for without the possibility of constative claims no language would exist at all in which the performative act could take place. In a rather different context - in his essay "Promises (Social Contract)" ${ }^{18}$ - but still talking about the

17. De Man, "Rhetoric of Persuasion," p. 129.

18. Paul de Man, "Promises (Social Contract)," in Allegories of Reading 246-77. 
constative and performative functions of language, de Man describes the same paradox in the following way: "It seems that as soon as a text knows what it states, it can only act deceptively ... and if a text does not act, it cannot state what it knows." 19 What the text performs, according to this statement, must be something else than what it knows, but if it does not perform it, that knowledge cannot be stated at all.

De Man's thoughts about the constative and performative functions of language, therefore, do not only explain but also criticise Wordsworth's poem. They show that the changes at the end of "Tintern Abbey" are necessary and organically follow from the structure of the whole poem, but they also disclose the weaknesses of this structure - or at least of the way Wordsworth uses it. What we learn thus is that Wordsworth necessarily changes the mode of his text from the constative to the performative but does not notice that the performative cannot fully replace the constative, that the act he needs at the end of his poem is only a deception, an aberration. He does not notice, furthermore, that in order to achieve the performative mode, he had to assume a role, the role of the teacher which is in itself a reduction of the complexities of selfhood which, apparently, his original aim was to explore. Wordsworth, when he assumes the role of the teacher, becomes the "lawgiver" but the lawgiver - as de Man says in "Promises (Social Contract)" - is always an impostor and a mere fiction: he promises but as he has no right to do this he also necessarily deceives by this promise.

To explain Wordsworth's blindness or naiveté we can give a number of reasons. We could say, for instance, that he was a pre-Nietzschean poet and thinker and thus was not aware of such subtleties. This would, of course, be a very naive explanation, for - although Wordsworth indeed preceded Nietzsche in time - he wrote after Rousseau in whose writings de Man discovers the same structures that Nietzsche described. We could also say that Wordsworth is in fact not really naive, that his text deconstructs itself, that with the conspicuous discrepancy between the quasi-religious fervour of the tone and the lack of substantiality in the content of this last section of his poem he himself draws attention to the deceptive, unfinished nature of the poem. This explanation would certainly be less naive and would probably be quite close to the explanation that de Man himself would have given had he ever come across the problem. Yet I think it would attribute too much subtlety and self-awareness to the poet which would in this case be absolutely unnecessary and an insult to rather then a compliment on the

19. De Man, “Promises,” p. 270. 
poet's genius. In the next part of this paper I will try, therefore, to find a third way to answer this question in order to avoid the difficulties present in both the possible answers mentioned above. I will try to prove that Wordsworth is neither too naive nor too subtle at the end of "Tintern Abbey" through arguing that the naiveté present at the end of the poem is in fact a necessary one: it is a naiveté that even Paul de Man must suffer his texts to embrace. I shall do this through analysing this time de Man's texts in the light of the structure given by Wordsworth in this closing section of "Tintern Abbey."

\section{III}

As I have mentioned above, the main difference between the way Wordsworth and de Man use this structure is that whereas in the poem it serves as the solution to the problems of the speaker, in de Man's essay it is only a means of deconstruction and as such it does not lead to any sure or final result. Thus having deconstructed in the Nietzschean way the validity of the constative function by the help of the performative, de Man immediately turns to the deconstruction of the performative. He says:

Lest we be inclined to read this text as an irreversible passage from a constative conception of language to a performative one, there are several other statements from the same general period [of Nietzsche's life] in which the possibility of 'doing' is as manifestly being deconstructed as the identity principle, the ground of knowledge, is being put in question here. ${ }^{20}$

Using some other Nietzsche texts from the same period, therefore, he shows that action in language is just as deceptive as the belief that language reflects the truth, that it reports about things as they exist in reality. What we used to deconstruct knowledge turns out to be less powerful than what was deconstructed by it and thus it cannot fully take the place of the first element, or, as de Man himself puts this, it "never reaches the symmetrical counterpart of what it denies." ${ }^{21}$ This pattern of insufficiency is then said to be characteristic of all deconstructive processes and thus of all language use; in de Man's own words "It is co-extensive with any use of language, and this use is compulsive or, as Nietzsche formulates it, imperative." 22

20. De Man, "Rhetoric of Persuasion,” p. 126.

21. De Man, "Rhetoric of Persuasion," p. 125.

22. De Man, "Rhetoric of Persuasion," p. 125. 
This statement, which is often made in different forms all through the essays of Allegories of Reading, seems to me to be a statement of a very powerful and convincing "I cannot" even if it is not accompanied - like in Wordsworth's case - with the feeling of regret or with any sense of loss. The reason why I still maintain that this structure is similar to an "I cannot" is that it is followed towards the end of the volume (more particularly in the penultimate essay of Allegories of Reading, "Promises (Social Contract)") by a gesture that in my opinion is very similar to the one Wordsworth makes at the end of "Tintern Abbey." The "I cannot" turns into an "I [or you] must:" de Man promises - or I should rather say that, even in spite of its author's intention, his text promises. It promises on two levels: first by announcing (and clearly this is de Man's intention) that language is structured so that texts must necessarily make promises; and then by enacting this theoretical observation, that is to say, by making (and de Man in my opinion is blind to this fact) an open promise to the readers.

In his "Promises (Social Contract)," de Man attempts to give "the linguistic model in general," 23 an allegory of textuality itself. To do this he analyses Rousseau's political writings and in particular the Social Contract. After a long discussion of the contractual discourse in general, he concludes that this particular Rousseau text is not only a deconstructive one, but it also goes beyond the everexisting constative/performative dilemma. De Man supports this claim by what I think is a reintroduction of a new, "transcendental" performative. All texts, according to him, are structured like an aporia: they keep performing what they have shown to be impossible to do. ${ }^{24}$ What these texts perform, however, is not always the same thing. What, for example, the Profession de foi and Julie (two texts he has analysed in two previous essays of Allegories of Reading) perform are two different things, even though the performance of these two things is similarly impossible. The first one keeps listening to, the second keeps loving that which has been shown to be impossible to listen to and to love, respectively. Listening and loving are, however, also similar to each other inasmuch as they are merely referential, transitive acts (like the constative function of knowing in the essay on Nietzsche). The Social Contract, in contrast to all these, performs something that goes beyond this referential function. In de Man's own words:

23. De Man, "Promises," p. 273.

24. De Man, "Promises," p. 275. 
What the Social Contract keeps doing however is to promise, that is, to perform the very illocutionary speech act which it has discredited and to perform it in all its textual ambiguity, as a statement of which the constative and the performative functions cannot be distinguished or reconciled. ${ }^{25}$

What makes the Social Contract special is, therefore, not that it keeps performing what it discredits but that what it performs is the very ground of all performing, the very ground of textuality itself: the constative/performative distinction. Consequently, the promise made in the contractual text - the allegory of all textuality - goes beyond the constative/performative opposition and grounds it in its possibility. In the contractual text, therefore, textuality is shown to become its own ground by performing, creating, as it were, what has always already preceded it as its (non-original) ground.

What de Man establishes here is, therefore, a kind of meta-performative. He reintroduces, in other words, the same constative/performative pattern that he used on Nietzsche on a higher level. What is more, he uses this pattern in a necessarily hierarchical construction, as if he disregarded the second half of his own Nietzsche essay. Although he has proved in this second half, and many times in other previous writings, that the constative and the performative cannot be clearly distinguished and that neither of them can be said to be prior to the other, here, at the end of "Promises (Social Contract)," he insists that the performative is still stronger, that it even transcends in this Rousseau text and - as this is a model of all language use - in all texts the very constative/performative opposition itself.

The original structure of the turning from the constative "I cannot" to the performative "I [or you] must" is, therefore, clearly present in this concluding statement about "the linguistic model in general"; and, what is more, it is apparently functional. Although he has many times shown in the previous essays of the book that this turning from the constative to the performative is an aberrant (though necessary) process as it does not produce the result for which it is implemented; de Man himself uses here the same pattern and is apparently not aware of its aberrant nature, not aware of the fact that he does not produce the result that he desires. Another surprising element in the statement quoted above is the conspicuous rhetorical effort and enthusiasm in its tone, which is otherwise quite unusual for de Man.

25. De Man, “Promises,” pp. 275-6. 
I must hasten to add that these surprising facts and shifts of emphasis at the end of "Promises (Social Contract)" do not at all strike the reader as unexpected or absurd. We are very well prepared for the reception of these changes, as de Man has already reintroduced his original structure (of the dialectic of performative and constative modes of language) previously to describe the general operation of the contractual model as established by Rousseau. The aporia that legislative or, more generally, political discourse has to face is - in this model that whereas on the one hand it can only be productive if it becomes perfectly technical, mechanical and general; on the other hand, it can only be put to use if it applies to particular cases. It must operate as a "constitutional machine," which is organised only by its inherent, grammatical laws; but at the same time it must be able to refer to a particular phenomenon. The solution to this dilemma, the passage from pure theory to its phenomenal manifestations, can only be achieved through a change in the mode of speech, through - as de Man says "a passage from constative theory to performative history." This process - de Man adds - can also be said to be the allegory of the inability of political discourse to achieve the status of a science, ${ }^{26}$ to make constative claims.

I think that de Man's original structure is clearly recognisable here: the constitutional machine whose operation is only possible inasmuch as it maintains its constative, purely theoretical, nature necessarily reaches an impasse, an "I cannot," and this then necessarily must turn into the performative, into the "I [or you] must." This whole process - again very much like in the original structure is accompanied by the appearance of temporality, more particularly by the introduction of futurity. To use de Man's own words: "the speech act of the contractual text never refers to a situation that exists in the present, but signals toward a hypothetical future" and "[a]ll laws are future-oriented and prospective; their illocutionary mode is that of the promise." 27

So far this structure is perfectly analogous with the one de Man used in "Rhetoric of Persuasion (Nietzsche)." The only - by no means insignificant difference is not in the structure itself but in the mode it is presented in the two different texts. In the former one on Nietzsche the passage from constative to performative was described only as a particular way of deconstructing the identity principle. It was a structure which in itself had no particular significance and which did not pertain to the nature of language. It was only a means through

26. De Man, "Promises," p. 273.

27. De Man, "Promises," p. 273. 
which the deconstruction could be effected and which itself was subject to the power of deconstruction. In the latter essay on Rousseau, however, the same process is presented as something that is a necessary development in the Social Contract and therefore is a general law of all language use. There is, therefore, a conspicuous turn here in de Man's mode of speech from the constative (which is merely concerned with what is susceptible of being spoken) to the performative (which posits the existence of what it talks about).

Besides these recurring elements and shifts of emphasis, there is also a wholly new constituent in the structure used to describe the working of the Social Contract. This new element is the "lawgiver." ${ }_{28}$ De Man argues that the "lawgiver" is necessary in the contractual text because the laws should express the general will of all the people, but the general will in itself is voiceless, it needs an individual to speak for it. This "lawgiver" is, therefore, necessarily an impostor, not really a person who has authority but rather a structural necessity of the text, a speaker whose existence is grounded by a figure of speech (more particularly by a metalepsis). ${ }^{29}$ The "lawgiver" is thus not a person but a role: the figure of a human voice that is assumed to be able to speak for the divine.

I have said that the impostor-lawgiver is a new element in the de Manian structure, yet I believe that this should not be a new element for the reader of the present paper, for (s)he should immediately recognise in this "lawgiver" the "teacher" of Wordsworth's poem. The teacher in "Tintern Abbey" is also just a role, a subterfuge. It is, however, a necessary one: the speaker of the poem can only achieve the authority that he desires, he can only achieve the level of generality necessary for him to be able to affirm, if he assumes this role. By assuming the role, however, he becomes an impostor thus undermining the authority which he was able to achieve only through the assumption of this role. This is what we can feel at the end of "Tintern Abbey," where the authority and convincing power of the speaker's voice is accompanied and undermined by an apparent epistemological, theoretical vagueness of the assertions made in the text. There is only one way to escape from this rather difficult situation and that is - as is shown by Wordsworth's case - that the impostor must claim to speak for the divine. The authority, which has been shaken by the fact of the subterfuge, can only be restored through direct reference to the divine authority. This is clearly what happens in "Tintern Abbey," for Wordsworth can only affirm his previously

28. De Man, "Promises," p. 274.

29. De Man, "Promises," p. 274. 
unsuccessful theories after he can announce "that Nature never did betray / The heart that loved her" (ll. 122-123; my italics). The reason why he can now speak in the voice of authority is, therefore, that Nature, the divine itself, has made the first step, has promised herself to us.

This element of the recourse to the action and promise made by the divine is, I think, a necessary element of the structure that has so far been described. It follows, therefore, that it must also be present in de Man's text, which - as has been indicated - is itself organised by the same pattern. So far I have only shown how de Man reintroduces this fundamental pattern in his analysis of the Social Contract as a necessary process of this particular Rousseau text and, by analogy, of all texts in general. De Man, however, does more than this: he himself enacts the same process or, to put it in another way, his text itself is organised by the same structure.

As I have already indicated, de Man's claim that the passage from the constative to the performative is a necessary tendency, a "must" in all texts, already marks a change in his position from the constative to the performative. This tendency is further strengthened when de Man asks the question whether Rousseau himself becomes the lawgiver of the Social Contract or not. His answer is, as is predictable, negative. This, however, does not mean that Rousseau never assumes the role of the lawgiver but rather that even if he does so occasionally, the lawgiver is still only an impostor, a role whose authority thus always remains questionable. If, therefore, Rousseau wants to remain the author of the Social Contract, if he wants to retain the status of his text as an allegory, he must be more than the lawgiver whose role he sometimes needs to impersonate but whose subterfuge he must remain aware of.

What de Man says after this, however, is much more interesting than this answer and shows a marked turn towards the performative inasmuch as in it de Man himself undertakes the task of promising. Having confirmed that the lawgiver's status is questionable, he does not draw the logical conclusion that the promises made in the text by this impostor are also questionable but introduces his theory of the "meta-performative," which I have referred to above. There is a need for the lawgiver - he seems to suggest -, because it is only him that can utter the promise. This promise itself, however, is something greater, something more than the lawgiver: it comes in fact from the text itself. This statement is obviously very far in its implications from de Man's previous claim that the text can only act deceptively. ${ }^{30}$

30. De Man, “Promises,” p. 270. 
Another very interesting element here is the way de Man supports his insistence on this meta-promise. Instead of giving structural reasons, he turns to something that is quite unusual for him: to empirical evidence which - again quite unexpectedly - he declares to be an undeniable proof of the existence of the promise as a necessary element of all texts. He gives two quotes from Rousseau's text and then concludes: "it is impossible to read the Social Contract without experiencing the exhilarating feeling inspired by a firm promise." ${ }^{31}$ If he accepts this as a legitimate argument, then he could have just as legitimately argued that the presence of divine authority is undeniable in the Social Contract because we can always feel this. This would, of course, not follow from the structure that de Man's text is built on but it clearly shows the seeming absurdity, or at least inconsistency, of the claim.

These unexpected changes at the end of the essay, however, again must not be looked at as mere inconsistencies or absurdities; they must be explained. And here Wordsworth's "Tintern Abbey" becomes very helpful, for what happens at the end of that poem is, I think, very similar to what happens at the end of de Man's essay. The seeming inconsistencies occur, therefore, not because of de Man's carelessness but because of a structural necessity in the text itself. He must now change the mode of his text into the mode of faith, into the mode of the promise, because this is a necessary development from the mode of the "I cannot" that the previous part of the essay, and in fact all the previous essays in Allegories of Reading, established. He must affirm to us in the form of a law, whose illocutionary mode is that of the promise, what he has always already believed in and what has always already grounded his argument all through the essays but what he has so far remained unable to control and to affirm. In order to achieve this, he must assume the role of the teacher, he must become the impostor and overlook the loss of epistemological control (apparent for instance in his recourse to empirical evidence) that goes together with this subterfuge.

Having questioned the authority of the lawgiver de Man faces the question "who is then making the promise if it cannot be the lawgiver?" and his answer as has been pointed out above - must inevitably be: the text itself. It is language itself - de Man declares - that keeps promising itself: "Die Sprache verspricht (sich)." " ${ }^{2}$ This is why - he argues - the Social Contract maintains the promise: not because of the author's intention but because "This model is a fact of lan-

31. De Man, "Promises," p. 276.

32. De Man, "Promises," p. 277. 
guage over which Rousseau himself has no control." 33 When de Man announces this, however, he obviously becomes an impostor himself. If it is true - as he maintains - that the promise is a fact of language and that it does not occur at the discretion of the writer, then it must follow that it cannot be consciously stated by anybody. If it is an immanent part of language then it must also be voiceless and unspeakable. It can only be expressed in the text by the help of a subterfuge, by introducing a "lawgiver" who must necessarily be an impostor, as well. And this is exactly what happens at this point of the essay. Just as at the end of "Tintern Abbey" Wordsworth assumes the role of the teacher, so at the end of his essay de Man must necessarily become the impostor of his own text announcing and affirming that which he has proved to be impossible for anyone to affirm.

De Man's original intention with shifting the authority from the "lawgiver" to the text itself was to eliminate the notion of divine authority from the contractual model, the model for all language use. What he achieves with this shift, however, is only a displacement or a new distribution of the roles. Instead of questioning the authority of the "lawgiver" he himself assumes this role, and instead of eliminating the necessary recourse to the divine authority he paradoxically makes language function as the divine.

What I mean by this latter statement becomes clearer if we put the sentence "die Sprache verspricht (sich)" in its original context, contrasting it with Heidegger's famous "die Sprache spricht." 34 Without going into the full complexity of this statement, I think that we can safely say that what Heidegger expresses with this assertion is that language exists in itself prior to everything else: it is sufficient to itself and does not need us for it to be what it is. Language is, therefore, the only thing that can be truly said to be, for it is independent of anything else whereas everything else in the world, including human beings as well, is entirely dependent on it. 35 This entirely self-sufficient "being," which alone can be said to be identical with itself and thus to be, is obviously analogous with Wordsworth's concept of nature, or with the God of the Judeo-Christian tradi-

33. De Man, "Promises," p. 277.

34. Martin Heidegger, "Der Weg zur Sprache," Gesamtausgabe, Vol. 12 (Unterwegs zur Sprache), ed. Friedrich-Wilhelm von Hermann (Frankfurt am Main: Klostermann, 1985), p. 243.

35. In his "Letter on Humanism" (Basic Writings, ed. D. F. Krell [London: Routledge, 1993] 217-65.) Heidegger famously says, "language is the house of being” (p. 217). 
tion. As this divinity is in all these cases entirely self-sufficient, however, we can have no access to it, just as we could have no access to language as it appears in Heidegger's famous statement if we had not already lived in this "house of being." This, however, cannot be sufficient for any serious thinker, for if this were true, then our whole discourse about these divinities would be impossible. There is only one way out of this situation: the divinity must be seen as giving itself. And this is exactly what happens in Wordsworth's poem, just as in de Man's essay. ${ }^{6}$ This "giving itself" is what de Man's statement expresses: this is why, in my opinion, the word "sich" becomes for him a necessary part of the statement.

This pattern is, of course, analogous with the one I have already presented when describing the ending of "Tintern Abbey." The teacher-impostor whose authority is questioned can regain this authority only by recourse to the divine power: Wordsworth must say "Nature never did betray / The heart that loved her" (ll. 122-3) and, similarly, the impostor de Man must say "Die Sprache verspricht sich."

All this, however, does not lessen the convincing power of the promise made at the end of de Man's essay, just as it did not lessen the effect of Wordsworth's victory at the end of "Tintern Abbey." The reason why we can still feel these statements convincing and powerful is that they are - in spite of their theoretical impossibility - necessary developments of the structure that organises both texts. Beyond the negative truth of the theory, which de Man talks so much about, there is, it seems, an even stronger force of structural necessity that drives the thinker towards affirmation, the affirmation of the truth in the future, in spite of the impossibility of such an act. This is what I think Jacques Derrida means when, in his Memoires: for Paul de Man, he describes de Man's achievement in the following way: "Underlying and beyond the most rigorous, critical, and relentless irony ... Paul de Man was a thinker of affirmation." 37 And the structure that Derrida uses to describe the form of this affirmation can very well be applied to the analysis I have presented in my paper of de Man's "Promises (Social Contract)," even though Derrida's reading of this text (in the third lecture of Memoires ${ }^{38}$ ) is very different from mine. He argues in the first lecture of the

36. Perhaps God's promising and then sending the Messiah can also be interpreted as representing the same structure in the Judeo-Christian tradition.

37. Jacques Derrida, Memoires: for Paul de Man (New York: Columbia University Press, 1986), p. 21.

38. Derrida, “Acts," in Memoires 89-153. 
Memoires 39 that de Man's affirmation takes place in the form of an alliance. He says, "This alliance is much more ancient, resistant, and secret than those strategic or familial manifestations that it must actually make possible and to which it is never reduced." 40 The first "yes" then with which de Man affirms, with which he commits himself to this alliance, had to be said before and beyond everything, before he sat down to writing at all. This "yes," however, is not enough in itself even if it is absolutely necessary and is the ground of everything else. The first affirmation, the first secret alliance must itself be affirmed again, this time expressly. De Man must commit himself to his first commitment, to keeping the memory of this first and primordial affirmation. He must say "yes" to that first "yes" "if anything is ever to come from the future." 41 And this second "yes," which Derrida so beautifully describes, is in my opinion most powerfully pronounced in de Man's essay on the promise.

If we accept that the final affirmation - even at the cost of the loss of epistemological control - is a necessary development of the pattern of thought that both Wordsworth and de Man used, then it follows that Wordsworth was in a sense right when he blindly performed the promise at the end of "Tintern Abbey." The naiveté in this act - which was revealed by the help of Paul de Man's description of the structure - was in fact a necessary one. We could say, therefore, that de Man, when seen as criticising the weakness of the affirmation, remains blind to the fact that this affirmation is necessary, so much so that even his own text must undergo the transformation that this necessity causes. In this sense then Wordsworth's text criticises de Man's blindness just as much as de Man's text has criticised Wordsworth's, and they both affirm the profundity of the insight that both texts have ultimately succeeded in conveying to us.

39. Derrida, "Mnemosyne," in Memoires 1-43.

40. Derrida, "Mnemosyne," p. 19.

41. Derrida, "Mnemosyne," p. 20. 